\title{
SUBSURFACE CONTAMINATION IN THE VADOSE ZONE BY LEACHATE AT FOUR OPEN REFUSE DUMPS IN MAIDUGURI, NORTH EAST NIGERIA
}

\author{
N. E. NWAIWU, M. AGWOKO AND B. GUJBAWU
}

(Received 8, November 2006; Revision Accepted 3, February 2009)

\begin{abstract}
The paper investigates the behaviour of four parameters namely chloride, sodium, potassium and nitrate underneath open dumps in an arid environment. Four sites were chosen for the study. These are University of Maiduguri (Unimaid), Lamisula, Wulari and the Kasuwa Shanu (Cattle Market) refuse dump sites. The first three are domestic solid waste dumps while the latter is an animal market waste dump. Soil samples were collected from these four dump sites. From each site was taken background sample at depths of $0.01 \mathrm{~m}$. All the parameters were detectable at all sites understudied at this depth. Chloride showed the clearest and most consistent behaviour at the four sites for the parameters tested. The consistency of chloride qualified it to be used a base for consideration to establish any other consistent parameter. Chloride and/or sodium can be used as conservative tracers in the vadose zone of the arid region to monitor the movement of leachate to protect the ground water system. The natural soil studied exhibited attenuation properties.
\end{abstract}

KEYWORDS: solid waste, ground water, vadose zone, conservative tracer, attenuation.

\section{INTRODUCTION}

Leachate is a liquid that results from water contaminants as it trickles through waste, agricultural pesticides or fertilizers, (Federal Environmental Protection Agency, 1991). There is health hazard associated with open dumping of refuse. These include menace of insects, rodents, foul odour apart from dotted and defaced urban aesthetic landscape (Ogunboye, 2003). Open dumps release various contaminants which lead to subsurface contamination (Ahel, Mikac , Cosovic and Proluc ,1999).

Groundwater has been exploited for domestic and other uses from earliest time (Genesis 26:18, The Holy Bible). The precise nature of its occurrence was not necessarily understood, but it has been successfully brought to the surface and groundwater use has been growing ever since (UNESCO-UNEP-WHO, 1992, 1996). Groundwater is particularly important in arid and semi-arid areas. There is a considerable degree of physico-chemical and chemical interdependence between the water and the containing material and the properties of both the ground and the water are important (UNESCO-UNEP-WHO, 1992, 1996). The unsaturated zone represents the first and most important natural defence against groundwater pollution (Lewis , Foster and Drasar, 1982; Foster, 1985; Matthess, Pekdeger and Schroter, 1985). This results from its position between the land surface and the water table. Additionally, a number of pollutant attenuation are more favoured by the environments of the soil and the unsaturated zone. Water movement in the unsaturated zone is largely vertical and normally slow (UNESCOUNEP-WHO, 1992, 1996). A previous work by Hojem (1988) showed that some lateral movement of contaminants in the subsurface occurs particularly when the depth of unsaturated soil below the landfill is large. The processes causing contaminant attenuation in the vadose zone include hydrodynamic dispersion, which causes dilution, and retardation ; filteration, sorption and cation exchange causing retardation and elimination; precipitation, hydrolysis and complexation causing elimination. Other causes of elimination include biochemical transformation and volatilization (Foster and Hirata, 1988; Gowler, 1983). The effectiveness and magnitude of treatment offered by these or other natural mechanisms depend on the geological and hydrological conditions at a specific site (Wangen and Jones, 1984). Natural soils have varying capacities for reducing migration rates of different chemical species through them (Fuller , 1978; Cartwright, Grifin and Gilkeson, 1977). Robinson, Carey, Watson and Gronov, (1999) monitored the Stangate East landfill in Kent, the United Kingdom and stressed that the use of attenuation processes can effectively protect the water environment. The results showed that degradation within the unsaturated zone was a significant mechanism in reducing concentration of organic contaminants. Retardation also was important in retarding the movement of ammoniacal and potassium ions through the unsaturated zone. The metal concentrations (iron and manganese) subsequently decreased as a result of changes in $\mathrm{pH}$ values.

N. E. Nwaiwu, Dept. of Civil and Water and Resources Engineering, University of Maiduguri, Maiduguri, Nigeria.

M . Agwoko, C/O Halima Gujbawu, Kaduna Polytechnic ,Kaduna State, Nigeria.

B. Gujbawu, C/O Halima Gujbawu, Kaduna Polytechnic ,Kaduna State, Nigeria. 
Dumping on land is one of the most widely used methods of the final disposal of solid wastes (Mavropoulos and Kallampakos, 1999; Stegmann, 1995) and in Nigeria are mostly, open dumps without liners and/or leachate collection systems. This creates the possibility of leakage of various contaminants from such dumps which can lead to severe ground water contamination (Christensen, 1992; Kendorff, 1995).

Related work on six unlined landfill sites in South Africa focused on subsurface contamination by leachate (Fourie, Blight and Pinheiro ,1999). The results showed that significant attenuation of contamination is possible in the unsaturated soil and if the rate of movement is slow, attenuation processes have a longtime in which contaminants may be treated naturally. The paper investigates the behaviour of four parameters namely chlorine, sodium, potassium and nitrate underneath open dumps in an arid environment.

\section{DESCRIPTION OF STUDY AREA.}

Maiduguri is the capital of Borno State in North East, Nigeria. It is located between longitude $13^{0} 14^{\prime} \mathrm{E}$ and $13^{\circ} 16^{\prime} \mathrm{E}$; and latitude $11^{\circ} 46^{\prime} \mathrm{N}$ and $11^{\circ} 54^{\prime} \mathrm{N}$ of the equator and occupies an approximate area of $200 \mathrm{~km}^{2}$ within the semi arid region of the Sudan Savannah. Maiduguri has a high temperature in the hot dry season which occurs between the months of February and May and an average rainfall of $691 \mathrm{~mm}$ (Nwaka, 1991).

\section{MATERIALS AND METHODS}

Four sites were chosen for the study. These are University of Maiduguri(Unimaid), Lamisula, Wulari and the Kasuwa Shanu (Cattle Market) refuse dump sites . The first three are domestic solid waste dumps while the latter is an animal market waste dump. Soil samples were collected from these four dump sites.

The first soil samples at the four sites were collected at $0.01 \mathrm{~m}$ depth after clearing away some of the refuse. Subsequent samples were collected at $0.2 \mathrm{~m}$ intervals up to $1.2 \mathrm{~m}$, then at $1.5 \mathrm{~m}$ and $2.0 \mathrm{~m}$. At this depth, the shovel could not be used for further digging and the auger ( $4 \mathrm{~m}$ in length, fabricated at the University of Maiduguri workshop), and used to collect samples at $3 \mathrm{~m}$ and $4 \mathrm{~m}$ depths. The samples were put into polythene bags and transported to the laboratory and stored at room temperature.

The soil was air-dried for 24 hours. Large lumps in each sample were broken and shaken through a sieve. The fraction passing was used for determination of contaminants. Prior to testing for potassium, sodium, chloride, and nitrate an extraction process was carried out. This consisted of mechanical agitation of the soil (in distilled water) for $2-2.5$ hours, followed by filteration of the suspension. The filterate was used for the analysis. Sodium and potassium were obtained using flame photometer.

\section{RESULTS AND DISCUSSION}

\section{Background Values}

From each site was taken background sample at depths of $0.01 \mathrm{~m}$. All the parameters were detectable at all sites understudied at this depth. The University of Maiduguri dumpsite had respective values for sodium, potassium, chloride and nitrate of 29.7, 113, 1.7 and $6.3 \mathrm{mg} / \mathrm{l}$. The Kasuwa Shanu dump results showed higher values than the Unimaid dump site. The values were $63.6,162.5,2.7$ and $15.4 \mathrm{mg} / \mathrm{l}$ for sodium , potassium, chloride and nitrate respectively. Detectable results were also measured at the Lamisula and Wulari dumpsites.

\section{Concentration Profiles}

Contaminant concentration profiles have been used to illustrate the nature and extent of pollution that has occurred at the various dump sites understudied. These are shown in Figures $1-4$. Below the background depth, all the parameters were detectable down to the $4 \mathrm{~m}$ depth. At the Lamisula dump (Figure 1), potassium had a background value of $157.5 \mathrm{mg} / \mathrm{l}$. There was a progressive reduction in the profile concentration up to a depth of 0.4 with a value of $120.5 \mathrm{mg} / \mathrm{l}$ at a depth $1.0 \mathrm{~m}$, the concentration of potassium under the Lamisula dump site increased to $125.5 \mathrm{mg} / \mathrm{l}$ from $120.5 \mathrm{mg} / \mathrm{l}$ at $0.4 \mathrm{~m}$. Another increment occurred at depth $1.0 \mathrm{~m}$ increasing the concentration to $118 \mathrm{mg} / \mathrm{l}$. Thereafter there was progressive reduction in concentration values giving a concentration of $24 \mathrm{mg} / \mathrm{l}$ at 4.0m depth. 


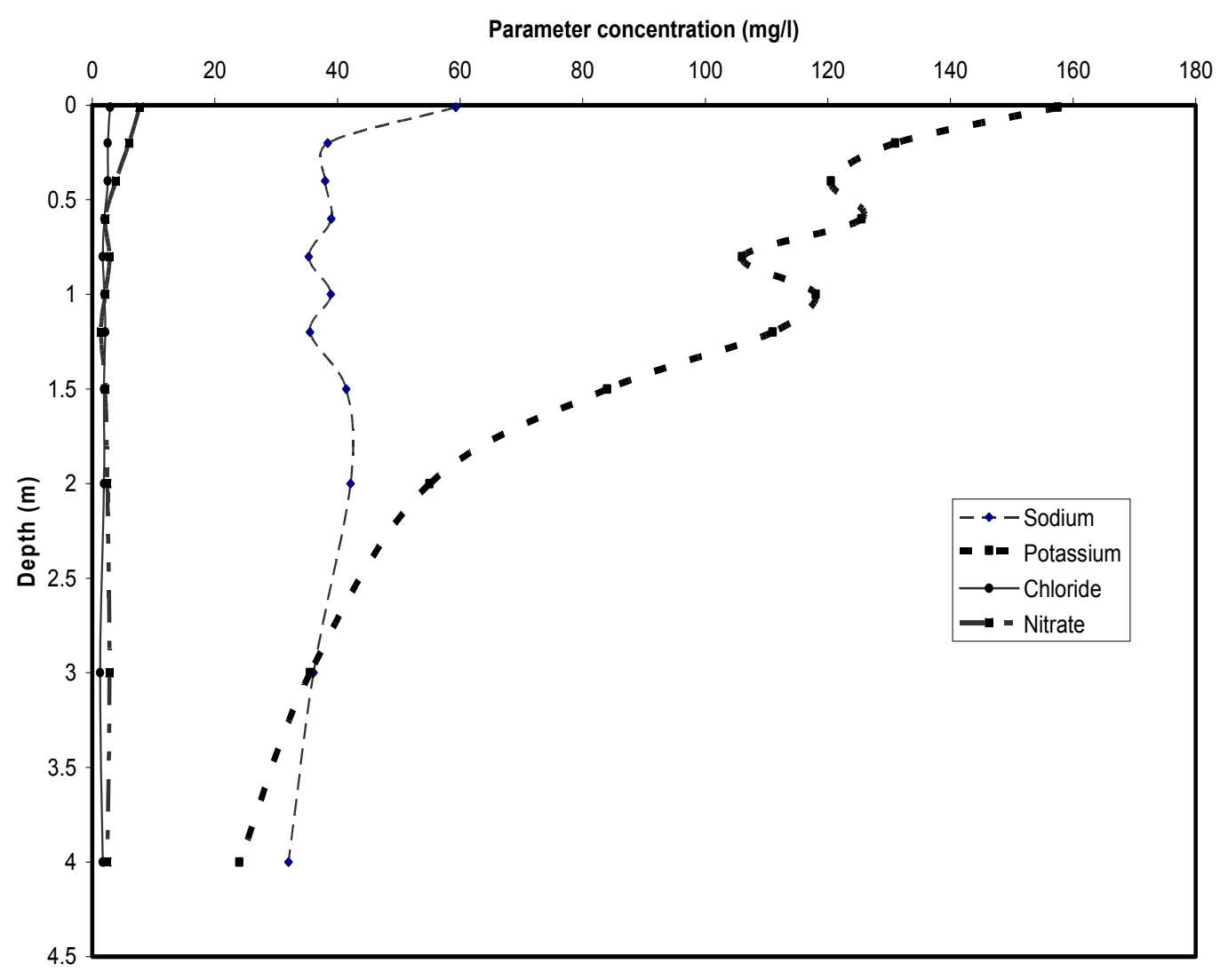

Fig 1 Concentration profile of parameters under the Lamisula refuse dump

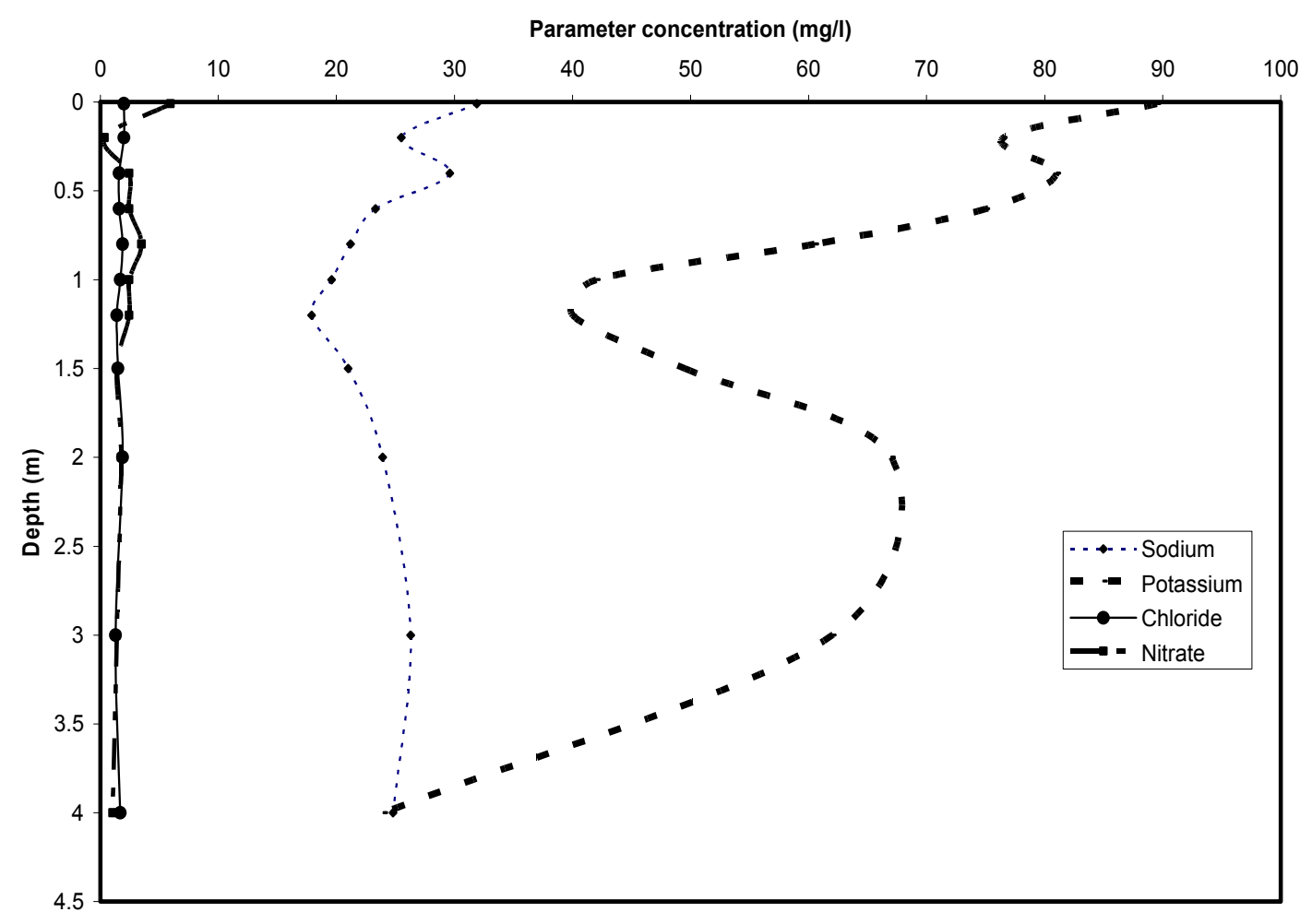

Fig 2 Concentration profile of parameters under the Wulari refuse dump 
The Wulari dump site concentration profile for sodium, potassium, chloride and nitrate are also shown (Figure 2). A reduction in the concentration profile of potassium occurred at the Wulari dump site upto a depth of $1.2 \mathrm{~m}(40 \mathrm{mg} / \mathrm{l})$ from a background value of $89.5 \mathrm{mg} / \mathrm{l}$. At depth $0.8 \mathrm{~m}$, the nitrate concentration markedly increased from $2.1 \mathrm{mg} / \mathrm{l}$ to $4.2 \mathrm{mg} / \mathrm{l}$.
The University of Maiduguri dump site had a background sodium concentration value of $29.7 \mathrm{mg} / \mathrm{l}$ (Figure 3). At the Unimaid dump site at depth $3.0 \mathrm{~m}$ an increase in concentration of potassium occurred from $18 \mathrm{mg} / \mathrm{l}$ to $22.5 \mathrm{mg} / \mathrm{l}$. Nitrate had an increment in concentration occurring at depth $1.2 \mathrm{~m}$ (concentration of $6.65 \mathrm{mg} / \mathrm{l})$ from a concentration of $1.4 \mathrm{mg} / \mathrm{l}$ at the $1.0 \mathrm{~m}$ depth.

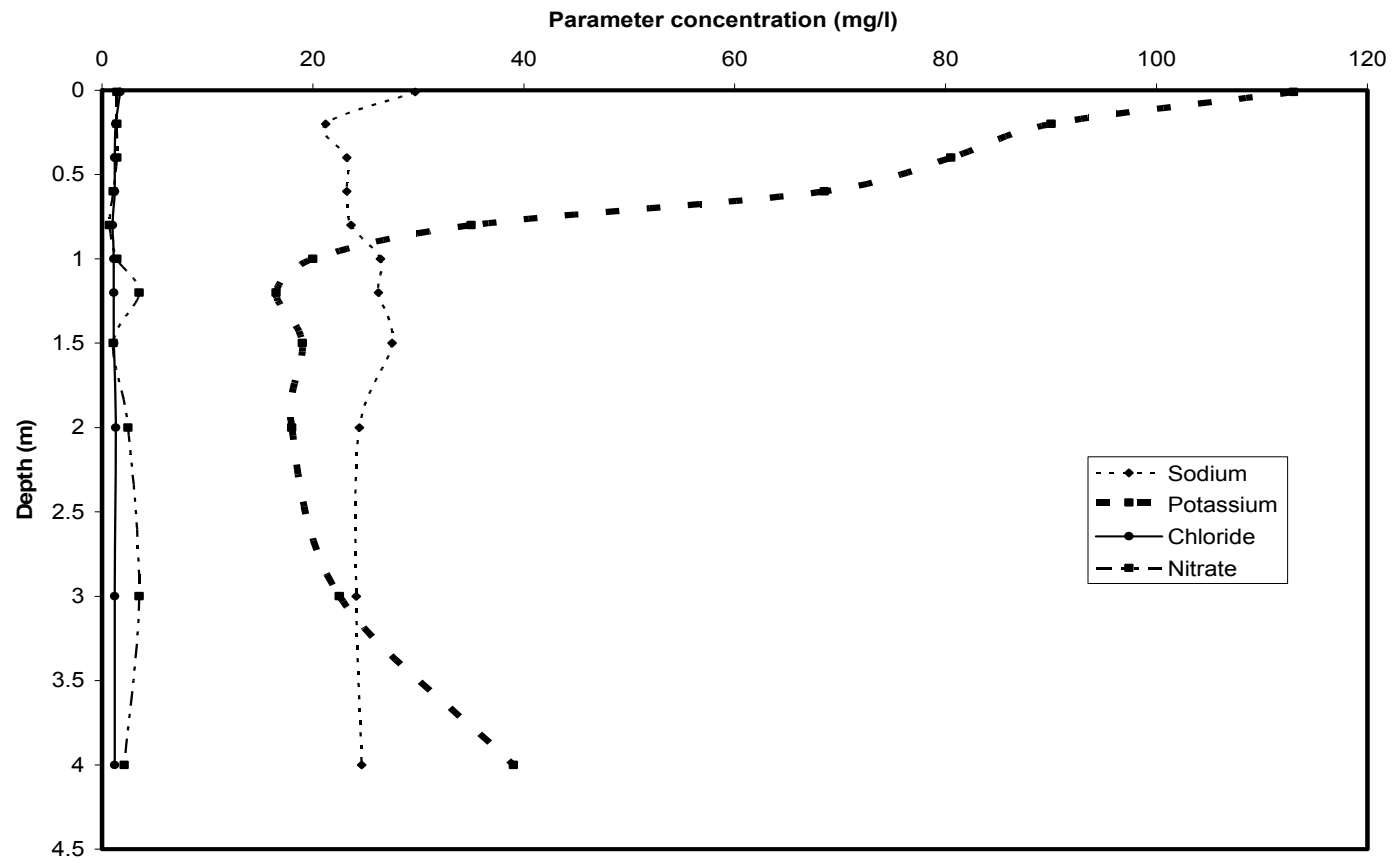

Fig 3 Concentration profile of parameters under the University of Maiduguri refuse dump

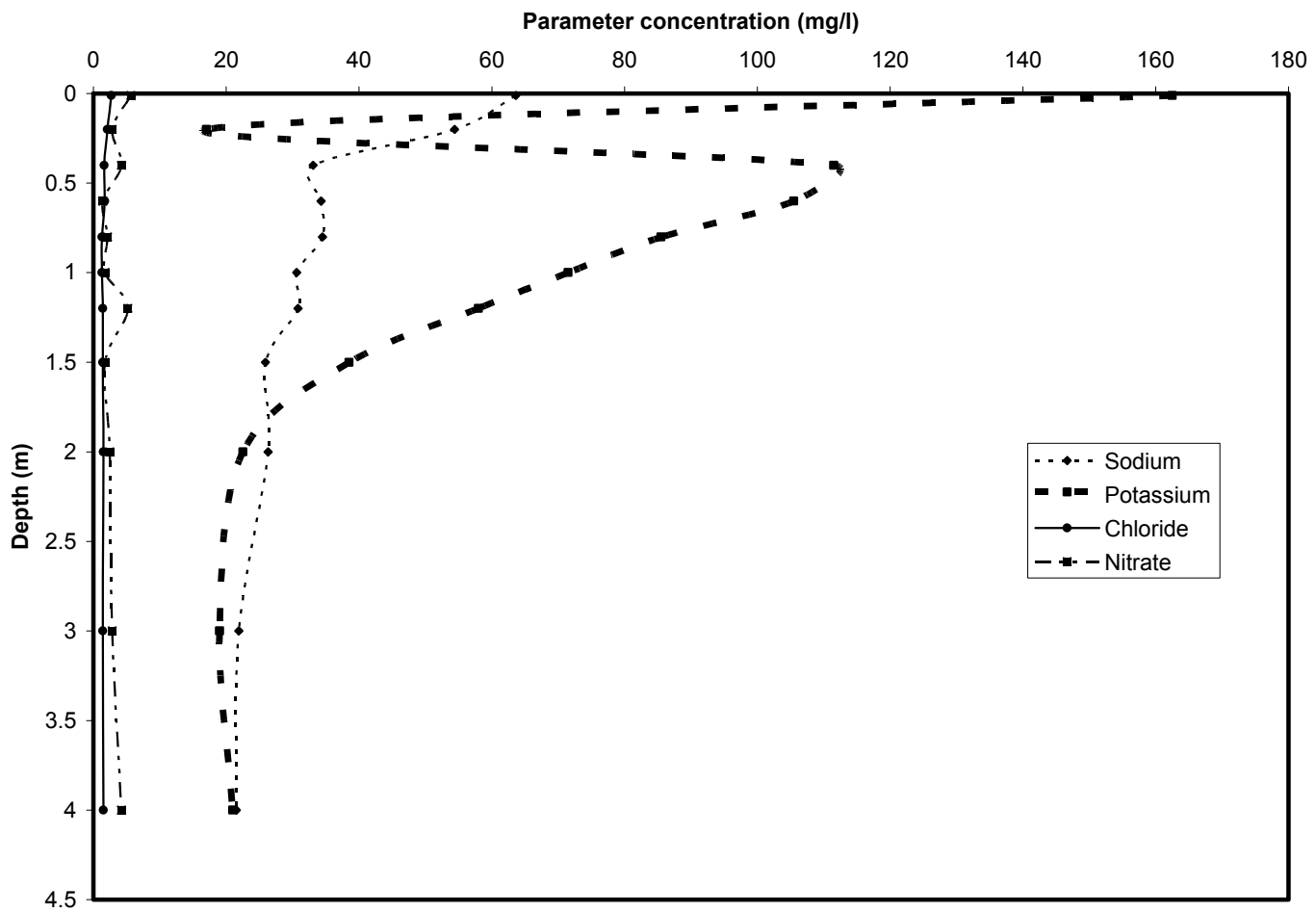

Fig 4 Concentration profile of parameters under the Kasuwan shanu refuse dump 
Table 1: Mean and Standard Deviation of Parameters

\begin{tabular}{|c|c|c|c|c|}
\hline Location & \multicolumn{3}{|c|}{ Parameters } \\
\hline & Sodium (Na) & Potassium (K) & Chloride (Cl) & Nitrate (NO ${ }_{3}$ ) \\
\hline Lamisula & $39.64 \pm 6.79$ & $97.09 \pm 40.39$ & $2.05 \pm 0.43$ & $3.25 \pm 1.82$ \\
\hline Wulari & $24.09 \pm 4.00$ & $60.64 \pm 19.04$ & $1.69 \pm 0.23$ & $2.29 \pm 1.42$ \\
\hline $\begin{array}{c}\text { University of } \\
\text { Maiduguri }\end{array}$ & $24.92 \pm 2.25$ & $47.46 \pm 32.86$ & $1.22 \pm 0.18$ & $1.81 \pm 0.92$ \\
\hline Kasuwan Shanu & $34.26 \pm 12.59$ & $64.77 \pm 45.41$ & $1.63 \pm 0.40$ & $3.11 \pm 1.38$ \\
\hline
\end{tabular}

At the Kasuwan Shanu refuse dump (Figure 4) sodium had a background value of $63.6 \mathrm{mg} / \mathrm{l}$. At $4 \mathrm{~m}$ depth, the sodium concentration was $21.5 \mathrm{mg} / \mathrm{l}$, potassium with a background value of $162.5 \mathrm{mg} / \mathrm{l}$ had a surge in concentration only at depth of $0.2 \mathrm{~m}$. Chloride shows the clearest and most consistent behaviour at all the four sites of all the parameters tested as shown in Table 1 with standard deviation ranging between $0.18-0.43$. This is the least range in comparison to all the other parameters studied. This is to be expected as chloride has a conservative behaviour and except by dilution is not affected by attenuation (Robinson and others, 1999). The existence of nitrate at the levels tested is a good indication that some contamination is present at the sites studied. Sudden increments in nitrate concentrations in all the dumps may indicate the movement of a contaminant slug (Fourie and others, 1999). used as a basis for consideration to establish any other consistent parameter. Consistent parameters are useful as conservative tracers. This comparison was achieved by plotting concentration ratios against depth in meters. The concentration ratios were obtained by dividing all other concentration values by the values at the $4.0 \mathrm{~m}$ depth for all parameters. These are shown in Figures 5 to 8 . The figures show sodium exhibiting properties very similar to chloride at all the sites. This qualifies sodium as a conservative tracer for use in the arid zone. At the Lamisula and Kasuwa Shanu refuse dumps, nitrate shows some similar behaviour to chloride unlike the University of Maiduguri and Wulari dumps. The nitrate concentrations reveal appreciable changes with profile; although Lewis and others (1980) and Fourie and others (1999) suggested nitrate as a conservative tracer in the unsaturated zone, this does not apply in the arid region studied.

The consistency of chloride qualified it to be

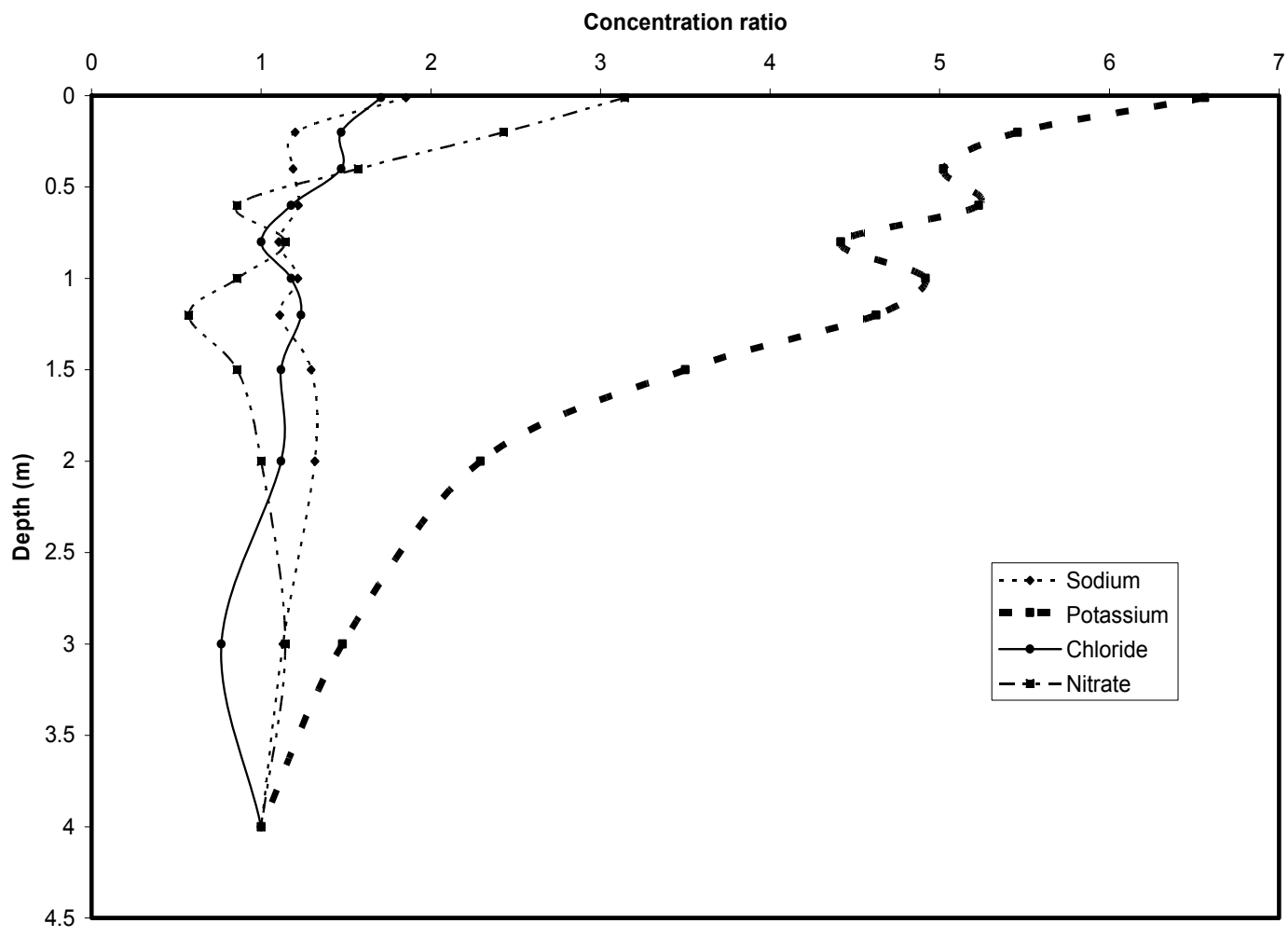

Fig 5 Concentration ratio profile of parameters under the Lamisula refuse dump 


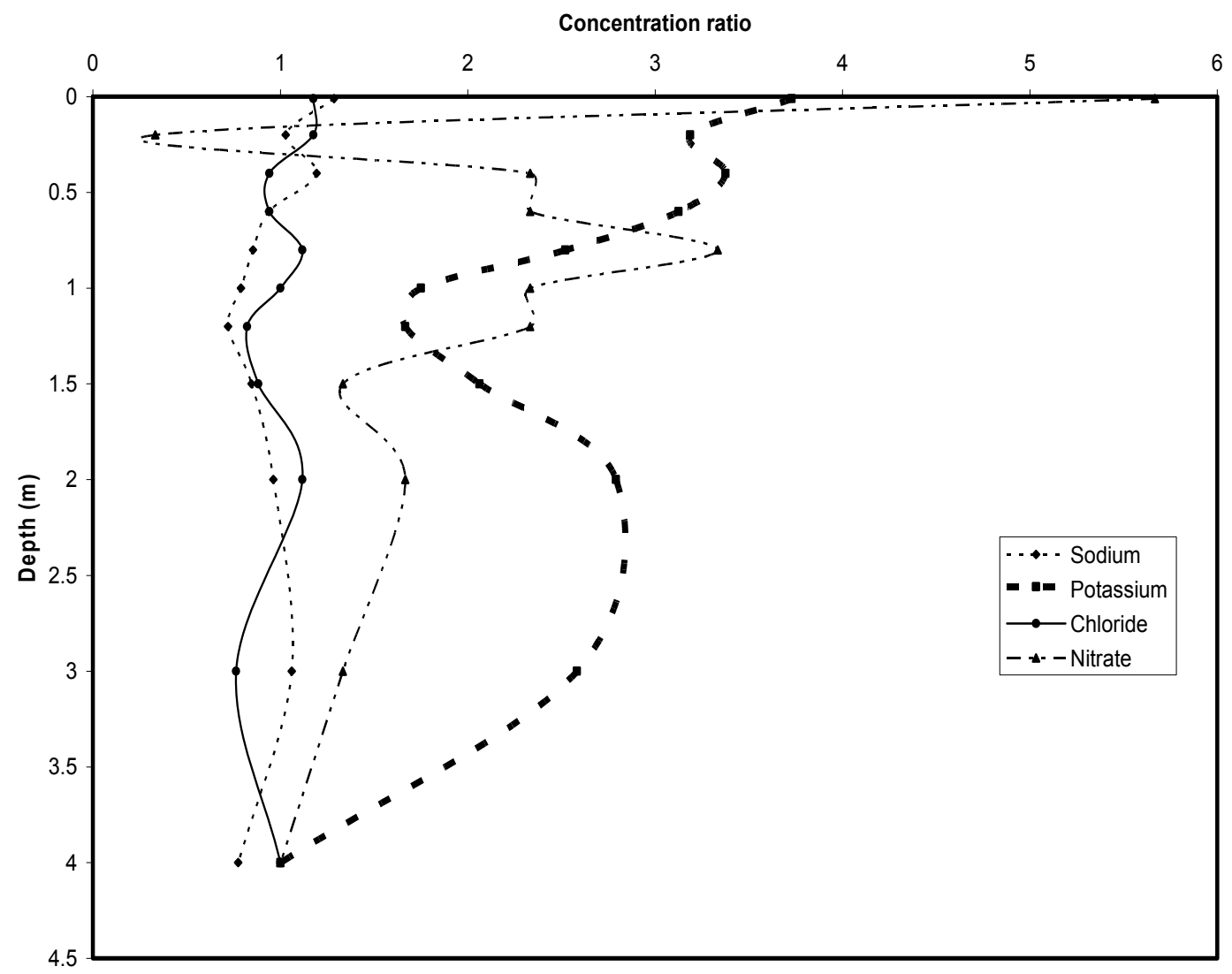

Fig 6 Concentration ratio profile of parameters under the Wulari refuse dump

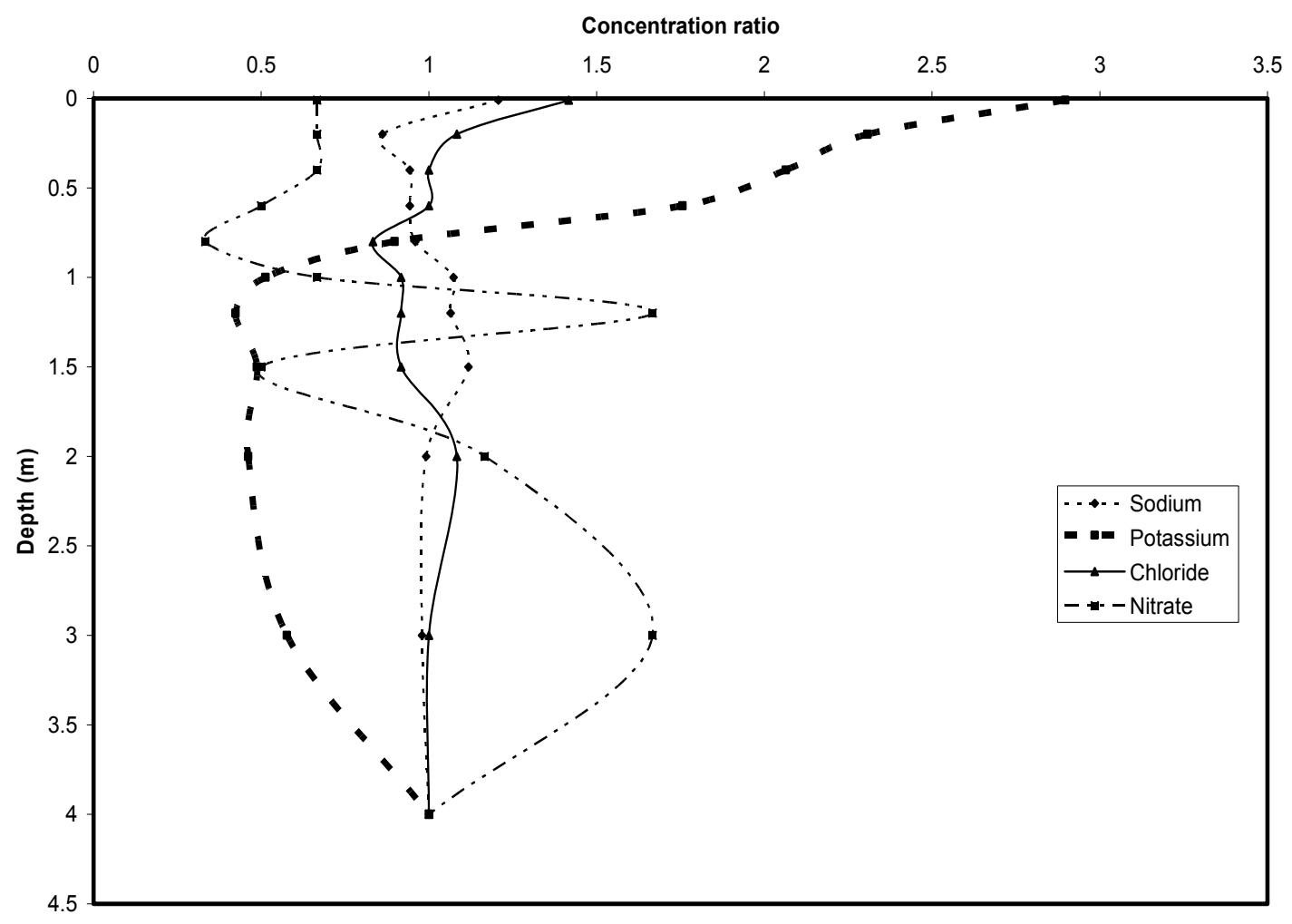

Fig 7 Concentration ratio profile of parameters under the University of Maiduguri refuse dump 


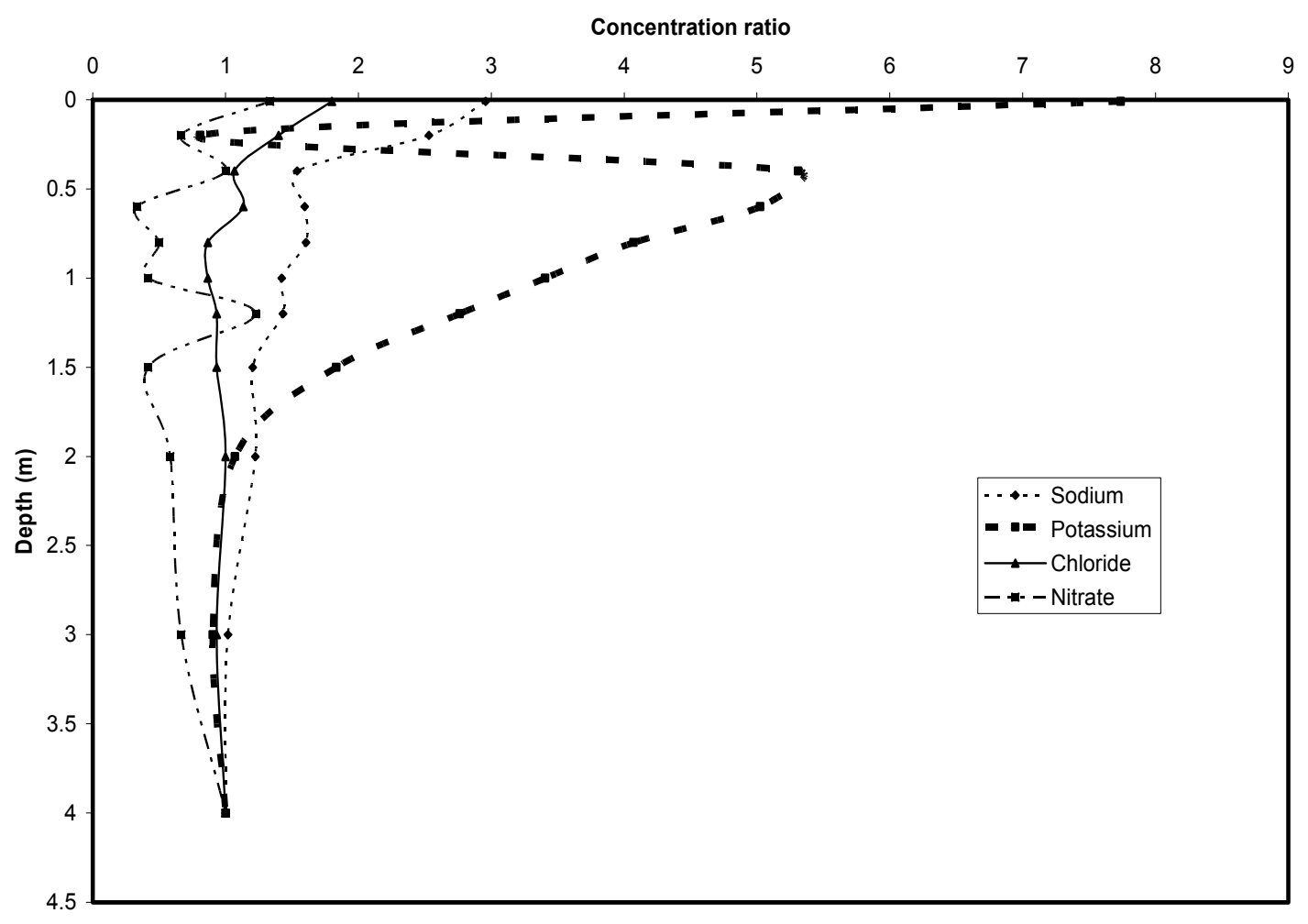

Fig 8 Concentration ratio profile of parameters under the Kasuwan Shanu refuse dump

\section{Attenuation properties}

Figure 9 shows the maximum attenuation for each parameter at the respective dumps. The results show that significant attenuation is possible in the unsaturated zone in Maiduguri. Nitrate was considered a conservative tracer by Fourie and others (1999) and Lewis and others. (1980). The present investigation does not present nitrate to have such a characteristic in the vadose zone of the arid region investigated. In all the refuse dumps, nitrate was attenuated to above $79 \%$ of the background value. The results for sodium and chloride are consistent with the finding of Robinson and others (1999) as conservative in nature.

Fig 9 Plot of Maximum Attenuation achieved by

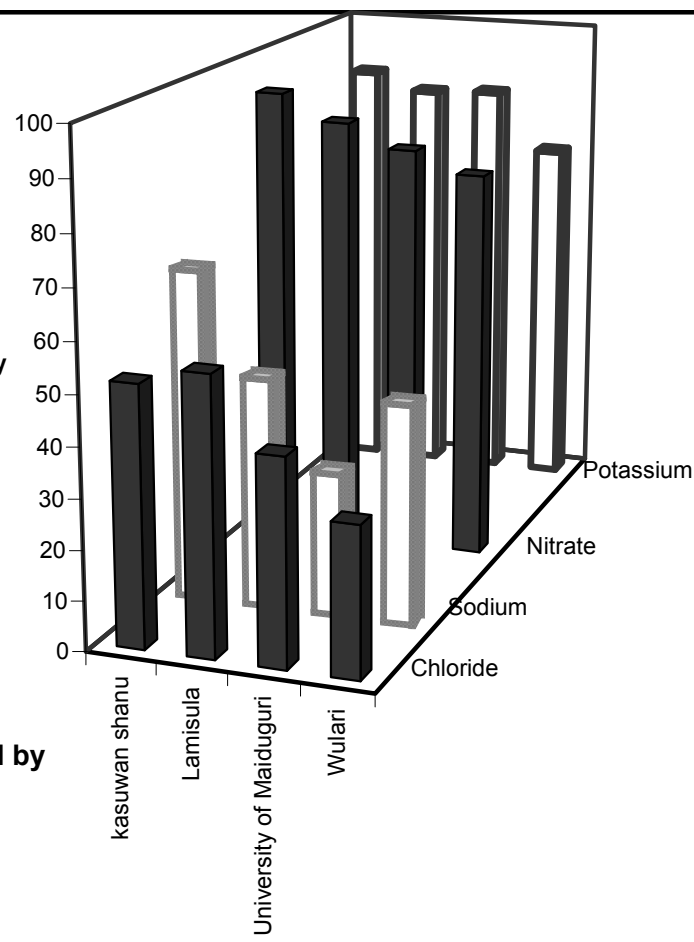

natural soil per

refuse dump(\%)

Maximum Attenuation by natural soil per refuse dump(\%) 


\section{CONCLUSION}

Soil samples obtained beneath four refuse dumps and at selected depth intervals up to a maximum depth of 4 metres were examined for chemical composition. Two cations (sodium and potassium) and two anions(chloride and nitrate) concentrations were evaluated for soils at each refuse dump site. For each location, potassium and nitrate varied significantly with depth while there was minimal variations of chloride and sodium with depth. Chloride and sodium can be used as conservative tracers in the vadose zone of the arid region to monitor the movement of leachate to protect the ground water system. As potassium and nitrite can be attenuated by the unsaturated zone, natural soil columns can be used to treat potassium rich waste waters.

\section{REFERENCES}

Ahel, M., Mikac, N., Cosovic, B. and Proluc, E., 1999. Transportation of Contaminants from an Unprotected landfill into adjacent groundwater aquifer. Proceedings, Sardinia 99, Seventh International Waste Management and Landfill Symposium, S. Margherita di Pula, Cagliari, Italy $141-148$

Cartwright, K., Grifin, R. A., and Gilkeson, R.H., 1977. Migration of landfill leachate through glacial tills: Ground Water . $15: 294-305$.

Christiansen, T. H., 1992. Attenuation of leachate pollutants in groundwater. Landfilling of waste: leachate. Christensen, T.H., Cossu, R. and Stegmann R (eds.) Elsevier, Applied Science, London. $441-483$.

Federal Environmental Protection Agency (1991): National Guidelines and Standards for Industrial Effluent, Gaseous Emissions and Hazardous Waste Management in Nigeria No. 58.

Foster, S. S. D., 1985. Groundwater pollution protection in developing countires in: G. Matthess, S.S.D. Foster, and A.C. Skinner (Eds) Theoritical background, hydrogeology and practice of groundwater protection zones. IAH International contributions to hydrogeology. Heinz Heise, Hannover, 6: 167 - 200.

Foster S. S. D. and Hirata, R., 1988. Groundwater pollution risk assessment. Pan American center for Sanitary Engineering and Environmental Science, Lima pp. 73

Fourie, A. B., Blight, G. E. and Pinheiro, J., 1999. Subsurface contamination by leachate at six unlined landfill sites in South Africa. Proceedings of Sardinia 99, Seventh International Waste Management and landfill Symposium S. margherita di pula Caliarin, Italy , 4-8 October 1999.133-140.
Fuller, W. A., 1978. Investigation of landfill leachate pollutant attenuation by soils. Environmental Protection Agency Report EPA - 600/2-78-158.

Gowler, A., 1983. Underground purification capacity. In: Groundwater in Water Resources Planning proceedings of the Koblenz Symposium IAHS. Publications 142, Volume 2, International Association of Hydrological Sciences, Wallingford, UK. 1063-1072.

Hojem, D. J., 1988. Water Balance and the migration of leachate into the unsaturated zone beneath a sanitary landfill. MSc. (Eng) dissertation, University of the Witwastersrand.

Kendorff, H., 1995. Groundwater contamination assessment by problem-specific selection of analytical parameters. Intern J. Environ. Anal. Chem, 60:.239-256.

Lewis, W. J., Foster, S. S. D. and Drasar, B. S., 1982. The risk of groundwater pollution by on-site sanitation in developing countries. IRCWD Report 01/82, RCWD, Duebendorf 79.

Matthess,. G, Pekdeger, A. and Schroter, J., 1985. Behaviour of contaminants in groundwater. In G. Matthess, S.S.D. Fosta and A.C. Skinner (Eds) Theoritical background, hydrogeology and practice of groundwater protection zones. IAH International contributions to hydrogeology. Volume 6, Heinz Heise, Hannover, 167 - 200.

Mavropoulos, A. and Kaliampakos, D., 1999. Investigation methodology for uncontrolled landfills. Proceedings Sardinia 99, Seventh International Waste Management and Landfill Symposium, S. Margherita di Pula, Cagliari, Italy.501-508.

Nwaka G. I. C., 1991. Pedogenic factors and soil resources of Borno State. Proceedings of $1^{\text {st }}$ International Conference on Arid Zone Hydrology and Water Resources.University of Maiduguri,Nigeria. 235-262.

Ogunboye, A. A., 2003. Institutional Framework for Managing Metropolitan Solid Waste: the Akure Experience . International Journal of Environmental Issues, 1 ( 2).In: UNESCOUNEP-WHO (1992, 1996). Water Quality Assessment. A guide to use biota, sediments and water in environmental monitoring $\left(2^{\text {nd }}\right.$ edition) $651 \mathrm{p}$.

Robinson, H., Carey, M., Watson, G. and Gronov, J., 1999. Insitu monitoring of the unsaturated zone beneath Stagnate East landfill site: sixteen years of detailed data, Proceedings Sardinia 99, Seventh International Waste Management and Landfill Symposium, S. Margherita di Pula, Cagliari, Italy.117-124. 
Stegmann, R., 1995. Concepts of waste landfilling, Proceedings, Sardinia $95,5^{\text {th }}$ Landfill Symposium Volume 1, Cagliari, Italy. Chnstensen, T.H.; Cossn R. and Stegman R. (eds) CISA. Cagliari . $2-12$.

The Holy Bible. The Authorized King James Version.

UNESCO-UNEP-WHO, 1992, 1996. Water Quality Assessment. A guide to use biota, sediments and water in environmental monitoring $\left(2^{\text {nd }}\right.$ edition) 651p.

Wangen, L. E. and Jones M. M., 1984. The attenuation of chemical elements in acidic leachates from coal mineral wastes by soils. Environ Geol. Water Science. 6(3):161-170. 